\title{
Classification of the journal category "oral surgery" in the Scopus and the Science Citation Index Expanded: flaws and suggestions
}

\author{
Seong-Gon Kim \\ Department of Oral and Maxillofacial Surgery, College of Dentistry, Gangneung-Wonju National University, Gangneung, Korea
}

\begin{abstract}
J Korean Assoc Oral Maxillofac Surg 2019;45:186-191)
Objectives: The aim of this study was to evaluate the journal category "oral surgery" in Scopus and in the Science Citation Index Expanded (SCIE). Materials and Methods: The Journal of Oral and Maxillofacial Surgery (JOMS), The Journal of the Korean Association of Oral and Maxillofacial Surgeons (JKAOMS), and The Journal of Prosthodontic Research (JPR) were selected from the Scopus list of journals as oral surgery journals. Maxillofacial Plastic and Reconstructive Surgery (MPRS) was selected from PubMed as a Scopus oral surgery title. From these titles, 10 recently published articles were collected and used for reference analysis.

Results: The percentage of citations from oral surgery journals was $26.7 \%, 24.5 \%$, and $40.1 \%$ for JKAOMS, MPRS, and JOMS, respectively. In total, $1.1 \%$ of JPR's citations were from oral surgery journals and significantly fewer from other journals $(P<0.001)$. The percentage of citations from dentistry journals excluding oral surgery journals was $11.9 \%, 34.4 \%$, and $15.8 \%$ for JKAOMS, MPRS, and JOMS, respectively. For JPR, $80.6 \%$ of citations were from dentistry journals and significantly more were from other journals $(P<0.001)$.

Conclusion: Selected samples revealed that JPR is incorrectly classified as an oral surgery journal in Scopus. In addition, the scientific interaction among JKAOMS, MPRS, and JOMS was different to JPR in the reference analysis.
\end{abstract}

Key words: Surgery, Oral cavity, Journal impact factor, Journal article, Periodicals

[paper submitted 2019. 1. 18 / revised 2019. 1. 29 / accepted 2019. 1. 29]

\section{Introduction}

There are numerous indexing services for journals, and most are not recognized by the government. Thus far, Science Citation Index Expanded (SCIE) and the Korean Citation Index $(\mathrm{KCI})$ are currently recognized by the Korean government. Scopus and PubMed are used as additional evaluation tools, but they are not widely accepted in Korea. However, some European countries use the h-index to evaluate individual performance among researchers; these data are provided by Scopus. Accordingly, the influence of Scopus has been

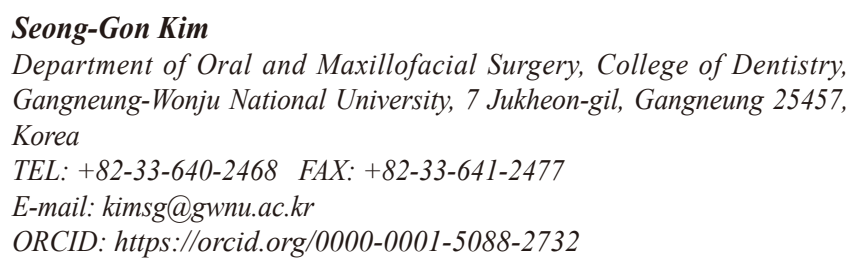

(2) This is an open-access article distributed under the terms of the Creative Commons Attribution Non-Commercial License (http://creativecommons.org/ licenses/by-nc/4.0/), which permits unrestricted non-commercial use, distribution, and reproduction in any medium, provided the original work is properly cited. Copyright (C) 2019 The Korean Association of Oral and Maxillofacial Surgeons. All rights reserved. expanded. Publishing a manuscript in a high-impact journal may be an advantage for researchers with regard to grants and reputation ${ }^{1}$. Accordingly, indexed journals with highimpact factors will have more opportunity to publish higher quality articles. Regional journals may lose the opportunity to publish high-quality articles and to be accepted by major indexing services. When this trend is combined with the underestimation of specific fields, scientific advancement can be delayed.

Dentistry journals have been underestimated by Clarivate Analytics and Scopus for several decades in comparison with medicine journals. Oral surgery and dentistry journals have been placed in the same category by Clarivate Analytics ${ }^{2}$. This practice has also been used with the medicine category as it comprises several fields, including allergy, anatomy, anesthesiology, cardiovascular system, clinical neurology, dermatology, and emergency medicine ${ }^{2}$. Scopus is much better than Clarivate Analytics because it classifies seven different fields as part of the dentistry category ${ }^{3}$. However, Scopus also has many flaws in their classification system. For example, the oral surgery category comprises 59 titles, but many may 
not be classified as an oral surgery title. Of these 59 titles, some no longer publish under the same name, including Dental Cadmos, Mund-, Kiefer- und Gesichtschirurgie, Oral Surgery, and Oral Surgery, Oral Medicine, Oral Pathology, Oral Radiology, and Endodontics. The Journal of Maxillofacial and Oral Surgery was indexed to Scopus, but it is not anymore. Because the category dental implantology comprises multidisciplinary fields, it should be classified separately. If these titles are excluded from the oral surgery category, only 26 titles remain in the oral surgery category of Scopus.(Table 1) We also selected titles that do not fall into the oral surgery category of Scopus.(Table 2) SCIE places dentistry, oral surgery, and medicine collectively in the same field ${ }^{2}$. The total number of journals in this field is 90 . Among them, only 10 titles may be classified as oral surgery titles.(Table 3 )

If the titles are from the same category, there should be similarity among research fields. This similarity can be proved by analyzing references ${ }^{1}$. The hypothesis of this study was that the titles in the same category would have higher

Table 1. Journal titles indexed to Scopus and properly classified as oral surgery

\begin{tabular}{cl}
\hline No. & \multicolumn{1}{c}{ Journal title } \\
\hline 1 & Asian Journal of Oral and Maxillofacial Surgery \\
2 & Atlas of the Oral and Maxillofacial Surgery Clinics of North \\
& America \\
3 & British Journal of Oral and Maxillofacial Surgery \\
4 & Cleft Palate-Craniofacial Journal \\
5 & Craniomaxillofacial Trauma and Reconstruction \\
6 & Dental Traumatology \\
7 & International Journal of Oral and Maxillofacial Surgery \\
8 & Italian Oral Surgery \\
9 & Journal of Cranio-Maxillo-Facial Surgery \\
10 & Journal of Oral and Maxillofacial Surgery \\
11 & Journal of Oral and Maxillofacial Surgery, Medicine, and \\
& Pathology \\
12 & Journal of Oral Medicine and Oral Surgery \\
13 & Journal of Stomatology, Oral and Maxillofacial Surgery \\
14 & Journal of the Korean Association of Oral and Maxillofacial \\
& Surgeons \\
15 & Medecine Buccale Chirurgie Buccale \\
16 & Minerva Stomatologica \\
17 & Operations Research for Health Care \\
18 & Oral and Maxillofacial Surgery \\
19 & Oral and Maxillofacial Surgery Cases \\
20 & Oral and Maxillofacial Surgery Clinics of North America \\
21 & Oral Oncology \\
22 & Oral Oncology Extra \\
23 & Oral Surgery, Oral Medicine, Oral Pathology and \\
24 & Oral Radiology \\
25 & Revista Española de Cirugía Oral y Maxilofacial \\
26 & Revue de Stomatologie et de Chirurgie Maxillo-Faciale \\
& Chirurgie Orale \\
\hline
\end{tabular}

Seong-Gon Kim: Classification of the journal category "oral surgery" in the Scopus and the Science Citation Index Expanded: flaws and suggestions. J Korean Assoc Oral Maxillofac Surg 2019 interactions. If some titles showed extremely low numbers of citations compared with other titles in the same category, the classification may be incorrect. The purpose of this article was to evaluate the classification system of major indexing services for journal titles in the oral surgery category by analyzing references, through which the relevance between the journal title and category could be determined.

\section{Materials and Methods}

Four different titles were selected arbitrarily for this analysis. The Journal of Oral and Maxillofacial Surgery (JOMS) ${ }^{4-13}$ was one journal title selected from journals indexed by Scopus and SCIE that was correctly classified as an oral surgery title.(Tables 1, 3) The Journal of the Korean Association of

Table 2. Journal titles indexed to Scopus and improperly classified as oral surgery

\begin{tabular}{cl}
\hline No. & \multicolumn{1}{c}{ Journal title } \\
\hline 1 & Archives of Orofacial Sciences \\
2 & Contemporary Clinical Dentistry \\
3 & Dental Cadmos \\
4 & Dental Press Journal of Orthodontics \\
5 & International Journal of Periodontics \& Restorative Dentistry \\
6 & International Journal of Prosthodontics \\
7 & Journal of Adhesive Dentistry \\
8 & Journal of Advanced Prosthodontics \\
9 & Journal of Indian Prosthodontist Society \\
10 & Journal of Oral Pathology \& Medicine \\
11 & Journal of Orofacial Orthopedics \\
12 & Journal of Orofacial Sciences \\
13 & Journal of Prosthetic Dentistry \\
14 & Journal of Prosthodontic Research \\
15 & Orthodontics and Craniofacial Research \\
16 & PROtech \\
17 & Protetyka stomatologiczna \\
18 & Revista Dental Press de Ortodontia e Ortopedia Facial \\
\hline
\end{tabular}

Seong-Gon Kim: Classification of the journal category "oral surgery" in the Scopus and the Science Citation Index Expanded: flaws and suggestions. J Korean Assoc Oral Maxillofac Surg 2019

Table 3. Journal titles indexed to Science Citation Index Expanded (SCIE) that can be classified as oral surgery journals

\begin{aligned} & \hline \multicolumn{1}{c}{ No. } \multicolumn{1}{c}{ Journal title } \\ & \hline 1 British Journal of Oral and Maxillofacial Surgery \\ & 2 Cleft Palate-Craniofacial Journal \\ & 3 International Journal of Oral and Maxillofacial Surgery \\ & 4 Journal of Cranio-Maxillofacial Surgery \\ & 5 Journal of Oral and Maxillofacial Surgery \\ & 6 Journal of Stomatology, Oral and Maxillofacial Surgery \\ & 7 Medecine Buccale Chirurgie Buccale \\ & 8 Oral and Maxillofacial Surgery Clinics of North America \\ & 9 Oral Oncology \\ & 10 Oral Surgery, Oral Medicine, Oral Pathology and Oral Radiology \\ & \hline\end{aligned}

Seong-Gon Kim: Classification of the journal category "oral surgery" in the Scopus and the Science Citation Index Expanded: flaws and suggestions. J Korean Assoc Oral Maxillofac Surg 2019 
Oral and Maxillofacial Surgeons (JKAOMS) ${ }^{14-23}$ was one journal title selected from the journals indexed by Scopus only and was correctly classified as an oral surgery title. (Table 1) One journal title that was selected from journals not indexed by Scopus or SCIE and classified as an oral surgery title was Maxillofacial Plastic and Reconstructive Surgery (MPRS) $)^{24-33}$. One journal title that was selected from journals indexed by Scopus and SCIE and incorrectly classified as an oral surgery title by Scopus (Table 2) was The Journal of Prosthodontic Research (JPR) $)^{34-43}$.

The inclusion criteria were (1) being an original article or a review article and (2) having at least 30 references. Editorials, case reports, and technical reports were excluded. Articles were collected beginning on January 1, 2018. When 10 articles that met the criteria were collected, collection was finished. If any journal title that met the inclusion criteria in 2018 had less than 10 articles, the deficiencies were replenished by the articles published in 2017.

The references were classified into three categories (oral surgery, dentistry, and other). Among Scopus- or SCIEindexed journals, classification as an oral surgery title was based on Tables 1 and 3. For unindexed titles, the terms "surgery" and "oral/maxillofacial" were used as the keywords for determining the classification category. Other titles in the dentistry category were classified as dentistry journals. Any title that was not classified as an oral surgery or dentistry title was classified as other.

After counting the total number of references in each ar-

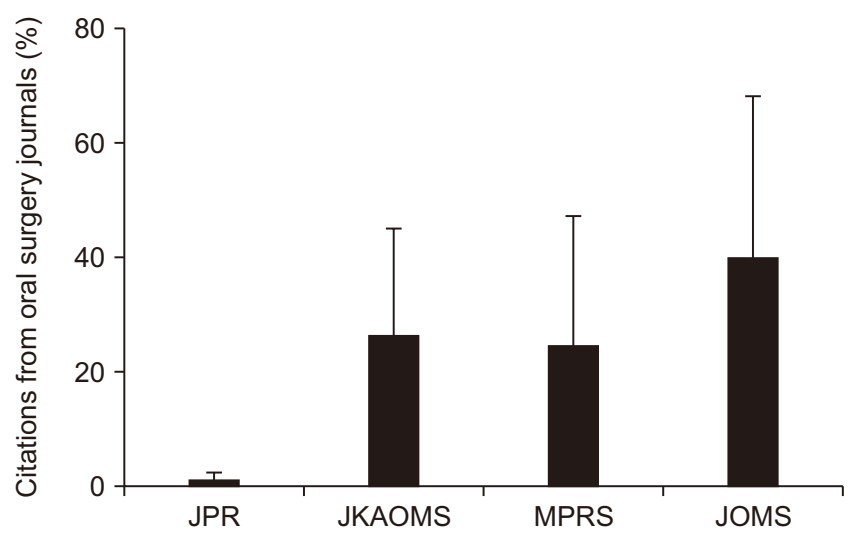

Fig. 1. The percentage of citations from oral surgery journals. JPR had a significantly lower value compared with other journal titles $(P<0.001)$. (JPR: The Journal of Prosthodontic Research, JKAOMS: The Journal of the Korean Association of Oral and Maxillofacial Surgeons, MPRS: Maxillofacial Plastic and Reconstructive Surgery, JOMS: The Journal of Oral and Maxillofacial Surgery) Seong-Gon Kim: Classification of the journal category "oral surgery" in the Scopus and the Science Citation Index Expanded: flaws and suggestions. J Korean Assoc Oral Maxillofac Surg 2019 ticle, the number of citations for each category was recorded. The ratio of citations among each category was calculated by dividing each value by the total number of references. The interaction between the three selected oral surgery titles and titles incorrectly classified by Scopus was analyzed.(Table 2) Additionally, the self-citation ratio was analyzed. Comparison of the four titles was done using ANOVA. For post hoc testing, Bonferroni's method was used. The level of significance was set at $P<0.05$. Statistical analysis was performed using IBM SPSS Statistics 23.0 (IBM Corp., Armonk, NY, USA).

\section{Results}

The total number of references for each journal title was 463, 362, 411, and 459 for JKAOMS, MPRS, JOMS, and JPR, respectively. In the case of MPRS, two articles were collected from 2017 . The rate of self-citation was $0.2 \%, 4.1 \%$, $10.2 \%$, and $2.0 \%$ for JKAOMS, MPRS, JOMS, and JPR, respectively. JOMS showed a relatively higher self-citation rate compared with the other three titles. When analyzing the citations in JKAOMS, MPRS, and JOMS from the titles listed in Table 2 , the percentage of citations was $0.4 \%$ for JKAOMS, $4.4 \%$ for MPRS, and $0.2 \%$ for JOMS.

The percentage of citations from oral surgery journals was $26.7 \% \pm 18.4 \%$ for JKAOMS, $24.5 \% \pm 22.7 \%$ for MPRS, and $40.1 \% \pm 28.0 \%$ for JOMS.(Fig. 1) However, the percentage of citations from oral surgery journals was only $1.1 \% \pm 1.3 \%$

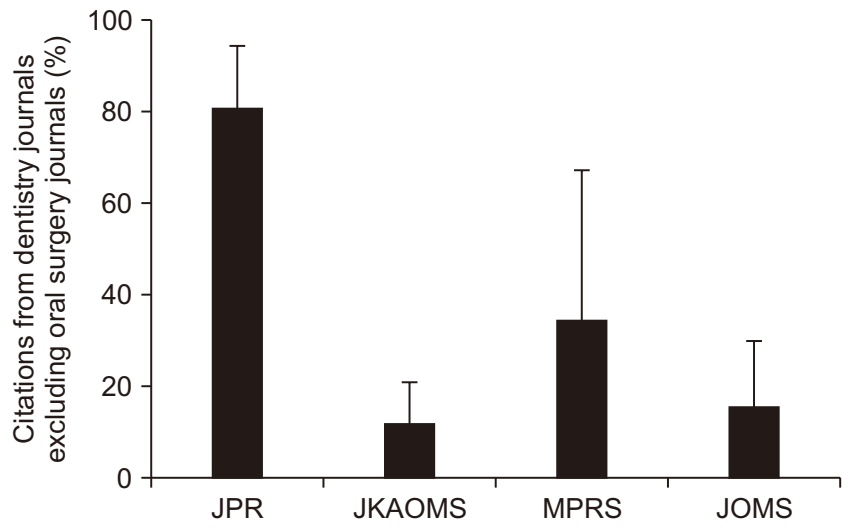

Fig. 2. The percentage of citations from dentistry journals excluding oral surgery journals. JPR had a significantly higher value compared with other journal titles $(P<0.001)$. (JPR: The Journal of Prosthodontic Research, JKAOMS: The Journal of the Korean Association of Oral and Maxillofacial Surgeons, MPRS: Maxillofacial Plastic and Reconstructive Surgery, JOMS: The Journal of Oral and Maxillofacial Surgery)

Seong-Gon Kim: Classification of the journal category "oral surgery" in the Scopus and the Science Citation Index Expanded: flaws and suggestions. J Korean Assoc Oral Maxillofac Surg 2019 
for JPR. This difference among groups was statistically significant $(P<0.001)$. On post hoc test, JPR had a significantly lower value compared with that of JKAOMS and JOMS ( $P=0.046$ and $P=0.001$, respectively).

The percentage of citations from dentistry journals excluding oral surgery journals was $11.9 \% \pm 9.2 \%$ for JKAOMS, $34.4 \% \pm 32.4 \%$ for MPRS, and $15.8 \% \pm 14.0 \%$ for JOMS (Fig. 2 ), while the percentage of citations from dentistry journals excluding oral surgery journals was $80.6 \% \pm 13.5 \%$ for JPR. The difference among groups was statistically significant $(P<0.001)$. On post hoc test, JPR had a significantly higher value compared with the other journal titles $(P<0.001)$.

\section{Discussion}

Considering the increasing influence of major indexing services on the scientific community, extremely few studies have evaluated indexing services. To the best of our knowledge, this was the first research evaluating indexing services in the oral surgery category. According to the selected samples, the current oral surgery category was flawed in both Scopus and SCIE. The interaction pattern based on the reference analysis of oral surgery titles such as JKAOMS, MPRS, and JOMS was significantly different compared with dental journals such as JPR.(Fig. 1,2) This preliminary study demonstrated that oral surgery journals had different patterns of interaction than dental journals and therefore should be classified as an independent category.

The percentage of citations from oral surgery journals was at least $20 \%$ in three oral surgery journals; however, it was approximately $1 \%$ for JPR.(Fig. 1) This is considered a major difference and should be considered an error in Scopus classification. Some authors claimed that a high percentage of mutual citations may be evidence of a citation cartel $^{1}$. However, a journal article having a reasonable number of mutual citations should help determine the journal category. Arbitrary selection criteria were used in this study to classify a journal as an oral surgery journal; the criteria were having the word "surgery" and "oral/maxillofacial" in the title. In this study all three selected titles showed similar performance.(Fig. 1) Thus, the selection criteria for classifying a title as an oral surgery title in this study seemed functional.

In the case of MPRS, the percentage of citations from dentistry journals excluding oral surgery journals was higher compared with the other two titles.(Fig. 2) The reason for this could be that articles associated with dental implants showed higher interaction with dentistry journals, and not oral sur- gery journals. Yu et al. ${ }^{24}$ and Kakar et al. ${ }^{25}$ were associated with implant restorations $87 \%$ and $73 \%$ of their citations, respectively, were from dentistry journals excluding oral surgery journals. In addition, MPRS includes articles about maxillofacial application of tissue engineering.

The percentage of citations from dentistry journals excluding oral surgery journals was higher in JPR.(Fig. 2) In the case of orthodontic journals, some articles show high interaction with oral surgery journals. One article that was selected from The American Journal of Orthodontics and Dentofacial Orthopedics (AJODO) had 25 references, 10 of which are from oral surgery journals and eight of which are from dentistry journals excluding oral surgery journals ${ }^{44}$. However, another article ${ }^{45}$ selected from the same journal did not have any references from oral surgery journals, despite having 55 references. Because there was a high level of variance in topics, collecting big data will be necessary to draw reliable conclusions.

The limitation of this study was that the number of selected samples was small considering the vast number of publications in the field of oral surgery and dentistry. There were no definite title selection criteria for each category. In addition, there were no guidelines about how to manage multidisciplinary fields of oral surgery having close interactions with other dental categories such as dental implantology ${ }^{6,24}$ and orthognathic surgery ${ }^{44}$. In this article, any title including the word "implant" in was excluded from oral surgery titles. In addition, any title including the word "orthodontic" was also excluded from the oral surgery category. These exclusions are not relevant to the clinical practice of oral surgery specialists. If all oral surgery/dentistry titles were included using a cross-reference database, more confirmative results could be obtained. Because this study was a preliminary pilot study, subsequent confirmative studies are needed.

\section{Conclusion}

Analysis of selected samples demonstrated that some oral surgery titles had low interaction with other oral surgery titles. Therefore, the decision to include or exclude a journal from a particular category in Scopus and SCIE should be reviewed. If errors are discovered, revisions should be made accordingly. In addition, the scientific interaction of oral surgery titles may vary from that for other dental titles. Thus, oral surgery titles should be separated from dentistry titles and established as an independent category. 


\section{Author's Contributions}

The study design and manuscript was written by S.G.K.

\section{Acknowledgments}

This study was carried out with the support of "Cooperative Research Program for Agriculture Science and Technology Development (project No. PJ01313902)," Rural Development Administration, Republic of Korea.

\section{Conflict of Interest}

The author is an editor of Maxillofacial Plastic and Reconstructive Surgery. That had no influence in study design, data collection and analysis, decision to publish, or preparation of the manuscript.

\section{References}

1. Chakraborty J, Pradhan D, Dutta HS, Nandi S, Chakraborty T. On good and bad intentions behind anomalous citation patterns among journals in computer sciences. Digital Libraries 2018; arXiv:1807.10804v1 [cs.DL].

2. Journal Search [Internet]. Philadelphia (PA): Clarivate Analytics [cited 2019 Jan 4]. Available from: http://mjl.clarivate.com/cgi-bin/ jrnlst $/$ jlsubcatg.cgi? $\mathrm{PC}=\mathrm{D}$.

3. Sources [Internet]. Amsterdam: Elsevier [cited 2019 Jan 4]. Available from: https://www.scopus.com/sources.uri?zone=TopNavBar \&origin $=$ searchbasic.

4. Ruela WS, de Almeida VL, Lima-Rivera LM, Santos PL, Porporatti AL, de Freitas PHL, et al. Does an association exist between the presence of lower third molar and mandibular angle fractures?: a meta-analysis. J Oral Maxillofac Surg 2018;76:34-45.

5. Lima TC, Bagordakis E, Falci SGM, Dos Santos CRR, Pinheiro MLP. Pre-emptive effect of dexamethasone and diclofenac sodium associated with codeine on pain, swelling, and trismus after third molar surgery: a split-mouth, randomized, triple-blind, controlled clinical trial. J Oral Maxillofac Surg 2018;76:60-6.

6. Anchieta RB, Guimarães MVM, Suzuki M, Tovar N, Bonfante EA, Atria P, et al. Nanomechanical assessment of bone surrounding implants loaded for 3 years in a canine experimental model. J Oral Maxillofac Surg 2018;76:71-9.

7. Maluf G, Caldas RJ, Silva Santos PS. Use of leukocyte- and platelet-rich fibrin in the treatment of medication-related osteonecrosis of the jaws. J Oral Maxillofac Surg 2018;76:88-96.

8. Susarla SM, Evans KN, Kapadia H, Vasilakou N, Egbert MA, Hopper RA. Distraction osteogenesis normalizes mandibular bodysymphysis morphology in infants with Robin sequence. J Oral Maxillofac Surg 2018;76:169-79.

9. Shirzadeh A, Rahpeyma A, Khajehahmadi S. A prospective study of chin bone graft harvesting for unilateral maxillary alveolar cleft during mixed dentition. J Oral Maxillofac Surg 2018;76:180-8.

10. Troeltzsch M, Probst FA, Rominger A, Müller-Lisse U, Probst M, Obermeier K, et al. Comorbidity assessment in patients with oral squamous cell carcinoma: can imaging techniques (fludeoxyglucose positron-emission tomographic computed tomography and contrast-enhanced computed tomography) provide additional infor- mation? J Oral Maxillofac Surg 2018;76:190-8.

11. Anand R, Shankar DP, Manodh P, Devadoss P, Aparna M, Neelakandan RS. Short-term evaluation of gustatory changes after surgical removal of mandibular third molar-a prospective randomized control trial. J Oral Maxillofac Surg 2018;76:258-66.

12. Zou L, He D, Ellis E. A comparison of clinical follow-up of different total temporomandibular joint replacement prostheses: a systematic review and meta-analysis. J Oral Maxillofac Surg 2018;76:294-303.

13. Quinelato V, Bonato LL, Vieira AR, Granjeiro JM, Tesch R, Casado PL. Association between polymorphisms in the genes of estrogen receptors and the presence of temporomandibular disorders and chronic arthralgia. J Oral Maxillofac Surg 2018;76:314.e1-9.

14. Alawode AO, Adeyemi MO, James O, Ogunlewe MO, Butali A, Adeyemo WL. A comparative study of immediate wound healing complications following cleft lip repair using either absorbable or non-absorbable skin sutures. J Korean Assoc Oral Maxillofac Surg 2018;44:159-66.

15. Malaviya P, Choudhary S. Zygomaticomaxillary buttress and its dilemma. J Korean Assoc Oral Maxillofac Surg 2018;44:151-8.

16. Lee JK. Dental management of patients on anti-thrombotic agents. J Korean Assoc Oral Maxillofac Surg 2018;44:143-50.

17. Khorasani M, Janbaz P, Rayati F. Maxillofacial reconstruction with Medpor porous polyethylene implant: a case series study. J Korean Assoc Oral Maxillofac Surg 2018;44:128-35.

18. Braimah R, Taiwo A, Ibikunle A, Oladejo T, Adeyemi M, Adejobi F, et al. Clinical experience in managing temporomandibular joint ankylosis: five-year appraisal in a Nigerian subpopulation. J Korean Assoc Oral Maxillofac Surg 2018;44:112-9.

19. Saghiri MA, Asatourian A, Sheibani N. Angiogenesis and the prevention of alveolar osteitis: a review study. J Korean Assoc Oral Maxillofac Surg 2018;44:93-102.

20. Lee DH, Kim IK, Cho HY, Seo JH, Jang JM, Kim J. Effect of herbal extracts on bone regeneration in a rat calvaria defect model and screening system. J Korean Assoc Oral Maxillofac Surg 2018:44:79-85.

21. Mamoun J. Dry socket etiology, diagnosis, and clinical treatment techniques. J Korean Assoc Oral Maxillofac Surg 2018;44:52-8.

22. Abouelhuda AM, Khalifa AK, Kim YK, Hegazy SA. Non-invasive different modalities of treatment for temporomandibular disorders: review of literature. J Korean Assoc Oral Maxillofac Surg 2018;44:43-51.

23. Adetayo AM, James O, Adeyemo WL, Ogunlewe MO, Butali A. Unilateral cleft lip repair: a comparison of treatment outcome with two surgical techniques using quantitative (anthropometry) assessment. J Korean Assoc Oral Maxillofac Surg 2018;44:3-11.

24. Yu SB, Song BG, Cheon KJ, Kim JW, Kim YH, Yang BE. Clinical reliability of zirconium abutment in implant restorations in the English and Korean literature. Maxillofac Plast Reconstr Surg 2018;40:26.

25. Kakar A, Kakar K, Sripathi Rao BH, Lindner A, Nagursky H, Jain $\mathrm{G}$, et al. Lateral alveolar ridge augmentation procedure using subperiosteal tunneling technique: a pilot study. Maxillofac Plast Reconstr Surg 2018;40:3.

26. An JH, Park SH, Han JJ, Jung S, Kook MS, Park HJ, et al. Treatment of dental implant displacement into the maxillary sinus. Maxillofac Plast Reconstr Surg 2017;39:35.

27. Yoon CS, Kim MK, Kim YS, Lee SK. In vivo protein expression changes in mouse livers treated with dialyzed coffee extract as determined by IP-HPLC. Maxillofac Plast Reconstr Surg 2018;40:44.

28. Shin SH, Kang YJ, Kim SG. The effect of botulinum toxin-A injection into the masseter muscles on prevention of plate fracture and post-operative relapse in patients receiving orthognathic surgery. Maxillofac Plast Reconstr Surg 2018;40:36.

29. Jung HM, Lee JE, Lee SJ, Lee JT, Kwon TY, Kwon TG. Development of an experimental model for radiation-induced inhibition of cranial bone regeneration. Maxillofac Plast Reconstr Surg 
2018;40:34

30. Mantelakis A, Iosifidis M, Al-Bitar ZB, Antoniadis V, Wertheim D, Garagiola $U$, et al. Proportions of the aesthetic African-Caribbean face: idealized ratios, comparison with the golden proportion and perceptions of attractiveness. Maxillofac Plast Reconstr Surg 2018;40:20.

31. Seok H, Kim SG, Kim MK, Jang I, Ahn J. Effect of the masseter muscle injection of botulinum toxin A on the mandibular bone growth of developmental rats. Maxillofac Plast Reconstr Surg 2018;40:5.

32. Oh JH. Recent advances in the reconstruction of cranio-maxillofacial defects using computer-aided design/computer-aided manufacturing. Maxillofac Plast Reconstr Surg 2018;40:2.

33. Hwang BY, Choi BJ, Lee BS, Kwon YD, Lee JW, Jung J, et al. Comparison between anterior segmental osteotomy versus conventional orthodontic treatment in root resorption: a radiographic study using cone-beam computed tomography. Maxillofac Plast Reconstr Surg 2017;39:34

34. Kutkut A, Bertoli E, Frazer R, Pinto-Sinai G, Fuentealba Hidalgo $\mathrm{R}$, Studts J. A systematic review of studies comparing conventional complete denture and implant retained overdenture. J Prosthodont Res 2018;62:1-9.

35. Castillo-Oyagüe R, Sancho-Esper R, Lynch CD, Suárez-García MJ. All-ceramic inlay-retained fixed dental prostheses for replacing posterior missing teeth: a systematic review. J Prosthodont Res 2018;62:10-23.

36. Yamaguchi S, Yamanishi Y, Machado LS, Matsumoto S, Tovar N, Coelho PG, et al. In vitro fatigue tests and in silico finite element analysis of dental implants with different fixture/abutment joint types using computer-aided design models. J Prosthodont Res 2018;62:24-30.

37. Warin P, Rungsiyakull P, Rungsiyakull C, Khongkhunthian P. Effects of different numbers of mini-dental implants on alveolar ridge strain distribution under mandibular implant-retained overdentures. J Prosthodont Res 2018;62:35-43.

38. Nasution H, Kamonkhantikul K, Arksornnukit M, Takahashi H. Pressure transmission area and maximum pressure transmission of different thermoplastic resin denture base materials under impact load. J Prosthodont Res 2018;62:44-9.

39. Kim DY, Kim JH, Kim HY, Kim WC. Comparison and evaluation of marginal and internal gaps in cobalt-chromium alloy copings fabricated using subtractive and additive manufacturing. J Prosthodont Res 2018;62:56-64.

40. Egilmez F, Ergun G, Cekic-Nagas I, Vallittu PK, Lassila LVJ. Does artificial aging affect mechanical properties of CAD/CAM composite materials. J Prosthodont Res 2018;62:65-74.

41. El-Damanhoury HM, Gaintantzopoulou MD. Self-etching ceramic primer versus hydrofluoric acid etching: etching efficacy and bonding performance. J Prosthodont Res 2018;62:75-83.

42. Tada H, Masaki C, Tsuka S, Mukaibo T, Kondo Y, Hosokawa $\mathrm{R}$. The effects of Lactobacillus reuteri probiotics combined with azithromycin on peri-implantitis: a randomized placebo-controlled study. J Prosthodont Res 2018;62:89-96.

43. Kubo M, Komada W, Otake S, Inagaki T, Omori S, Miura H. The effect of glass fiber posts and ribbons on the fracture strength of teeth with flared root canals restored using composite resin post and cores. J Prosthodont Res 2018;62:97-103.

44. Pelo S, Gasparini G, Garagiola U, Cordaro M, Di Nardo F, Staderini E, et al. Surgery-first orthognathic approach vs traditional orthognathic approach: oral health-related quality of life assessed with 2 questionnaires. Am J Orthod Dentofacial Orthop 2017;152:250-4.

45. Varga S, Spalj S, Anic Milosevic S, Lapter Varga M, Mestrovic S, Trinajstic Zrinski M, et al. Changes of bite force and occlusal contacts in the retention phase of orthodontic treatment: a controlled clinical trial. Am J Orthod Dentofacial Orthop 2017;152:767-77.

How to cite this article: Kim SG. Classification of the journal category "oral surgery" in the Scopus and the Science Citation Index Expanded: flaws and suggestions. J Korean Assoc Oral Maxillofac Surg 2019;45:186-191. https://doi.org/10.5125/jkaoms.2019.45.4.186 